\title{
Ethnicity and social cohesion in the post-Soviet Baltic states
}

\section{Nils Muiznieks , Juris Rozenvalds \& leva Birka}

To cite this article: Nils Muiznieks, Juris Rozenvalds \& leva Birka (2013) Ethnicity and social cohesion in the post-Soviet Baltic states, Patterns of Prejudice, 47:3, 288-308, DOI: 10.1080/0031322X.2013.812349

To link to this article: http://dx.doi.org/10.1080/0031322X.2013.812349

里 Published online: 04 Jul 2013.

Submit your article to this journal $\widetilde{ }$

Џلll Article views: 430

Q View related articles $\llbracket$

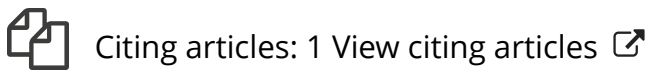




\title{
Ethnicity and social cohesion in the post-Soviet Baltic states
}

\section{NILS MUIZNIEKS, JURIS ROZENVALDS AND IEVA BIRKA}

\begin{abstract}
This article examines the efforts of post-Soviet Estonia, Latvia and Lithuania to promote social cohesion by addressing the ethnic and linguistic cleavages that are part of the legacy of Soviet rule. In examining the particular situation of each Baltic state and the response to international pressure for integration and social inclusion policy, Muiznieks, Rozenvalds and Birka note the roles of threat-perception, the historic context, the linguistic and citizenship policy, as well as socio-economic inequality, in facilitating Russian-speakers' sense of belonging to their respective Baltic state. While ostensibly aimed at fostering a sense of belonging to the national state, Baltic integration and social inclusion policy has often had a contradictory effect, especially in Estonia and Latvia, where the emphasis on the majority language and culture as a prerequisite for access to citizenship and formal membership has enhanced the threat-perceptions of minorities, and led to their alienation or identification with the external homeland of Russia. In Lithuania, early inclusion of minorities into the polity has had a beneficial long-term impact in terms of their identification with their country of residence, demonstrated by the fact that Russian-speakers express a greater sense of belonging to Lithuania. A review of the available survey data on the Baltic states suggests that the same cannot be said for Estonia and Latvia, where minorities express a weak sense of belonging to the state. This suggests a challenging road ahead for Estonia and Latvia in achieving social cohesion, understood by minorities as a sense of membership in the community and feelings of mutual recognition. Furthermore, all three Baltic states, Latvia in particular, have yet to address growing socio-economic inequality, which threatens to cause long-term difficulties for social cohesion.
\end{abstract}

KEYWORDS Baltic states, belonging, citizenship, Estonia, Latvia, Lithuania, minorities, Russian-speakers, sense of belonging, social cohesion, social integration, socio-economic inequality

L ithuania, Latvia and Estonia participate in broader European debates and policy initiatives on social cohesion, social inclusion and the integration of immigrants and refugees. However, the focus in the Baltic region to date has not been on addressing socio-economic inequality or the adaptation of the small number of post-Soviet new arrivals. Rather, the Baltic states have sought to overcome ethno-political and linguistic cleavages that are part of the legacy of Soviet rule. In Estonia and Latvia in particular, the emphasis 
has been on the integration of the large post-war Russian-speaking settler populations and their descendants.

This article examines Baltic efforts to promote social cohesion, efforts that have been hampered by the Soviet legacy of unequal bilingualism and the resulting sense of cultural threat perceived by majorities, particularly in Estonia and Latvia. Less salient threat-perceptions have permitted Lithuania to opt for an early inclusion of minorities in the polity, a decision that has positively contributed to that country's efforts to instil among minorities a sense of belonging to the Lithuanian state.

Latvia and Estonia have been less successful at facilitating minorities' sense of belonging and have largely focused on linguistic policy as a means of civic and cultural integration. While all three Baltic states have placed a disproportionate emphasis on language policy, the less demographically fraught context in Lithuania has meant that the linguistic measures have not been as controversial and have been decoupled from citizenship policy.

In socio-economic terms, Estonia has had the best record in promoting equality; however, it continues to struggle with more pronounced ethnic stratification than the other Baltic countries. In order to highlight the achievements and failures of social cohesion, the final section of the article will provide a review of the available survey data on the Baltic states to reflect popular opinions and the feelings of belonging among their residents. The review suggests that, more than twenty years after independence, there remain serious challenges ahead for Estonia and Latvia in fostering a sense of belonging among minorities.

\section{Historical context}

As can be seen in Table 1, the ethnic composition of the three Baltic states has undergone massive change since the interwar years of independence (191840). The ethnic predominance of Lithuanians in their territory has remained constant, though the size of the Polish community increased after the Second World War with the transfer of Vilnius from Polish to Soviet control. In Estonia and Latvia, the size of the indigenous ethnic group decreased significantly after 1940, due to war deaths, flight to the West, deportations to the East and the massive post-war immigration of Soviet workers. At the same time, the size of the Russian population grew significantly until 1989, when it began to decline somewhat due to emigration in the early 1990s.

The challenge to social cohesion posed by ethnic diversity has been exacerbated by past Soviet policy, which did little to promote knowledge of the local languages and cultures among settlers or to encourage contact between them and Balts. Soviet policy granted a privileged role to the Russian language in all the USSR's republics, including in the Baltic. Settlers were provided with few opportunities and incentives to learn the local languages, while their children could acquire education from kindergarten 
Table 1 Ethnic composition of the Baltic states from the interwar years to the present (\%)

\begin{tabular}{llcrrr}
\hline & & Indigenous ethnic & Russian & Polish & Other \\
\hline \multirow{4}{*}{ Interwar period } & Lithuania (1923) & 83.9 & 2.7 & 3.2 & 10.2 \\
& Latvia (1935) & 75.5 & 10.6 & 2.5 & 11.4 \\
& Estonia (1934) & 88.2 & 8.5 & 0.1 & 3.2 \\
1989 & Lithuania & 79.6 & 9.4 & 7.0 & 4.0 \\
& Latvia & 52.0 & 34.0 & 2.3 & 11.7 \\
& Estonia & 61.5 & 30.3 & 0.2 & 8.0 \\
& Lithuania (2011) & 83.9 & 5.4 & 6.6 & 4.1 \\
& Latvia (2009) & 59.3 & 27.8 & 2.4 & 10.5 \\
& Estonia (2010) & 68.8 & 25.5 & 0.1 & 5.6 \\
\hline
\end{tabular}

Sources: For the interwar years, Andres Kasekamp, A History of the Baltic States (Basingstoke: Palgrave Macmillan 2010), 17; for 1989, Goskomstat SSSR, Natsional'nyi sostav naseleniia SSSR (Moscow: Finansy i statistika 1991), 9-19; for 2010, national statistics offices.

through to university in Russian. Non-Russian minorities (such as Ukrainians, Belarusians, Poles etc.) were deprived of their cultural and educational infrastructures and many came to regard Russian as their native language (hence the term 'Russian-speakers').

At the same time, knowledge and use of Russian was promoted through various means, and Russian was the lingua franca in the Soviet military and other security services, the Communist Party and large segments of the economy. As can be seen in Table 2, this resulted in asymmetric bilingualism, whereby many settlers remained monolingual Russian-speakers unable to communicate with the Balts except in Russian, which became widely used among the indigenous ethnic or 'titular' populations, especially in Latvia.

Ethnolinguistic cleavages acquired political and security aspects during the independence struggle from 1988 to 1991. Significant segments of the minority communities in all three Baltic states joined overwhelmingly Slavic 'internationalist movements' that forged an alliance with pro-Soviet Communists and the security services loyal to Moscow. In Latvia and Estonia,

Table 2 Language competence of Balts and Russians in the Baltic republics, 1989

\begin{tabular}{lcccc}
\hline Republic & $\begin{array}{c}\text { Titular } \\
\text { population }\end{array}$ & $\begin{array}{c}\text { \% Claiming } \\
\text { knowledge of } \\
\text { Russian }\end{array}$ & $\begin{array}{c}\text { Russian } \\
\text { population }\end{array}$ & $\begin{array}{c}\text { \% Claiming } \\
\text { knowledge of titular } \\
\text { language }\end{array}$ \\
\hline Estonia & 963,269 & 33.6 & 474,815 & 13.7 \\
Latvia & $1,387,647$ & 65.7 & 905,515 & 21.2 \\
Lithuania & $2,924,048$ & 37.4 & 343,597 & 33.5 \\
\hline
\end{tabular}

Source: Goskomstat SSSR, Natsional'nyi sostav naseleniia SSSR. 
about a third of all Russian-speakers supported the pro-Soviet movement. ${ }^{1}$ In Lithuania, the pro-Soviet movement-called Vienybè-Edinstvo-Jednosč (Unity) — united both anti-independence Russian-speakers and a significant segment of Poles. While these movements demobilized after independence in 1991, doubts about their 'loyalty' among Balts remained.

In Estonia and Lithuania, the minority issue has had a stronger regional dimension than in Latvia, where all the major cities have a significant Russian-speaking minority and sometimes even a majority. In Estonia, in addition to settling in the capital Tallinn, approximately one-third of the Russian-speaking population is concentrated in the northeastern county of Ida-Virumaa, where it constitutes an overwhelming local majority. In Lithuania, ethnic Poles and Russians are concentrated not only around the capital Vilnius, but also in the southeastern part of the country, where half the population is Lithuanian and one-third is Polish.

The spatial distribution of minorities has affected the intensity of interethnic contact as well as the nature of the demands emanating from the minority communities. In the late 1980s, about 90 per cent of ethnic Estonians and Lithuanians entered endogamous marriages, while in Latvia the figure was about 80 per cent. In both Lithuania and Estonia, there were unsuccessful attempts on the part of minorities to gain territorial autonomy, in certain heavily Polish districts of Lithuania during the independence struggle and in the northeast of Estonia in 1992-3.

\section{The post-Soviet transformation and the 'nationalization' of citizenship}

In the autumn of 1991, Estonian and Latvian legislators adopted citizenship acts according to which all residents who had been citizens on 16 June 1940 and their descendants had their citizenship rights 'restored'. This 'restoration' meant that all post-war settlers and their descendants - about 740,000 inhabitants of Latvia and 500,000 of Estonia - overnight became 'non-citizens' (in Latvia's terminology) or 'aliens' (in Estonia's terminology). ${ }^{2}$ Accordingly, these 'non-citizens' could not participate in the first post-independence parliamentary elections, which took place in Estonia in 1992 and in Latvia in 1993.

Thus, legal means were used to diminish the political influence of post-war settlers and their descendants, who were left with three options: taking the

1 Nils Muiznieks, 'The pro-Soviet movement in Latvia', Report on the USSR (Radio Free Europe/Radio Liberty), vol. 2, no. 34, 1990, 19-24; Toomas Hendrick Ilves, 'Reaction: the Intermovement in Estonia', in Jan Arveds Trapans (ed.), Toward Independence: The Baltic Popular Movements (Boulder, CO: Westview Press 1991), 71-84 (73).

2 Nils Muiznieks (ed.), Latvia Human Development Report 1995 (Riga: United Nations Development Programme 1995), 22; Vadim Poleshchuk, Non-Citizens in Estonia. Report 2004 (Tallinn: Legal Information Centre for Human Rights 2004), 9. 
citizenship of another country (usually Russia), naturalizing or remaining 'non-citizens' /'aliens'. The Estonian authorities initially required all 'aliens' to acquire 'temporary residence permits', implying the possibility that they could be revoked and that 'aliens' would then lose their right to residency in Estonia. This generated significant fears among 'aliens' about their status, and many acquired citizenship of the Russian Federation. In Latvia a 1995 law granted 'non-citizens' permanent residence rights automatically. As a result, on 1 May 2013, 122,746 persons in Estonia had citizenship of another country, of which 93,795 (or 76.4 per cent) were citizens of the Russian Federation. ${ }^{3}$ At the beginning of 2013, Latvia, by contrast, had only 66,188 foreign citizens, of which 43,586 (65.9 per cent) were citizens of the Russian Federation. ${ }^{4}$

In Estonia, naturalization began in 1992, while in Latvia not until 1995. Naturalization initially took place in Estonia according to the rather liberal provisions of the 1938 law on citizenship. Thus, as can be seen in Figure 1, more than half of all naturalizations overall $(87,712$ of 154,874) from 1992 to 2012 took place in the period 1992 through 1996. In a 1995 law, citizenship requirements were made stricter and all candidates had to pass a language examination, leading to a significant drop in naturalization rates.

In 1994 Latvia adopted a citizenship law that implemented rather strict linguistic and other requirements; it also created a system of 'age brackets' whereby a timetable (from 1996 through 2003) was created in which different categories of 'non-citizens' were allowed to submit applications depending on where and when they were born and arrived in Latvia. As a result of concerted arm-twisting by the EU, the Organization for Security and Co-operation in Europe (OSCE) and some member states, Latvian legislators proposed amendments to the citizenship law to remove the system of age brackets that had limited the scope of those eligible to apply for citizenship, and to allow the possibility of registering stateless children born in Latvia without any examinations. The amendments were sufficiently controversial that they were put to a referendum in October 1998 in which the majority of citizens approved them. ${ }^{5}$ In December 1998 the Estonian parliament also amended its citizenship act to grant citizenship on easy terms to stateless children. ${ }^{6}$ As can be seen in Figure 1, this change led to a significant jump in naturalization rates in Latvia, which peaked immediately after EU accession in 2004.

3 'Citizenship', 1 May 2013, available on the Estonia.eu website at http://estonia.eu/ about-estonia/society/citizenship.html (viewed 8 May 2013).

4 Pilsonības un migrācijas lietu pārvalde (PMLP, Office of Citizenship and Migration Affairs), 'Latvijas iedzīvotāju sadalījums pēc valstiskās piederības', 1 January 2013, available on the PMLP website at www.pmlp.gov.lv/lv/statistika/dokuments/2013/ ISVP_Latvija_pec_VPD.pdf (viewed 8 May 2013).

5 Nils Muiznieks and Ilze Brands Kehris, 'The European Union, democratization and minorities in Latvia', in Paul J. Kubicek (ed.), The European Union and Democratization (London: Routledge 2003), 30-55 (39-42).

6 Vello Pettai and Kristina Kallas, 'Estonia: conditionality amidst a legal straightjacket', in Bernd Rechel (ed.), Minority Rights in Central and Eastern Europe (London and New York: Routledge 2009), 104-18 (111). 
Figure 1 Naturalization rates in Estonia and Latvia, 1992-2012

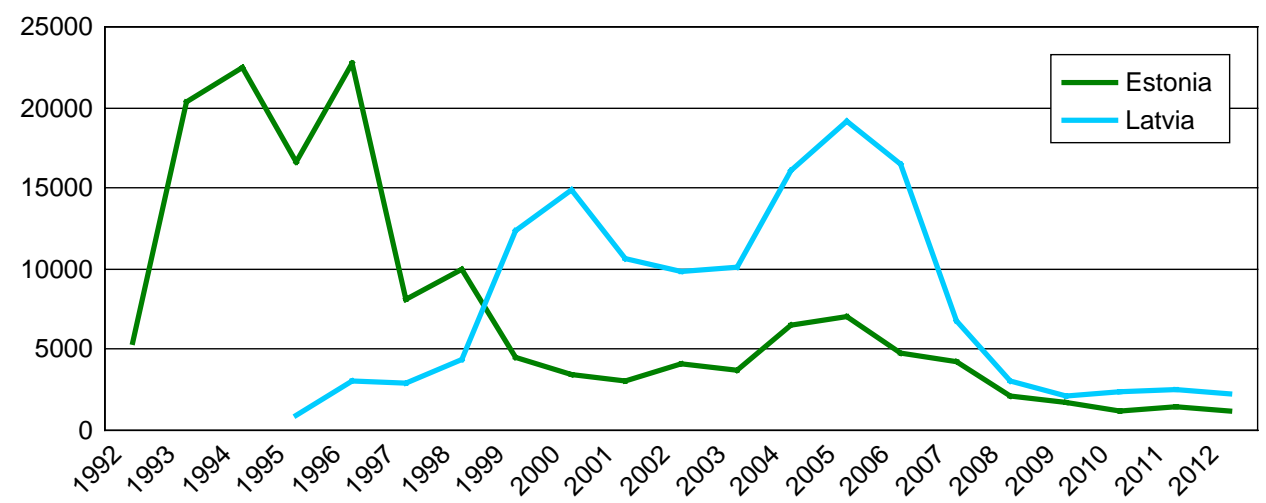

\begin{tabular}{llllllllllll}
\hline & $\mathbf{1 9 9 2}$ & $\mathbf{1 9 9 3}$ & $\mathbf{1 9 9 4}$ & $\mathbf{1 9 9 5}$ & $\mathbf{1 9 9 6}$ & $\mathbf{1 9 9 7}$ & $\mathbf{1 9 9 8}$ & $\mathbf{1 9 9 9}$ & $\mathbf{2 0 0 0}$ & $\mathbf{2 0 0 1}$ & $\mathbf{2 0 0 2}$ \\
\hline Estonia & 5421 & 20370 & 22474 & 16674 & 22773 & 8124 & 9969 & 4534 & 3425 & 3090 & 4091 \\
\hline Latvia & & & & 984 & 3016 & 2992 & 4439 & 12427 & 14900 & 10637 & 9844 \\
\hline & $\mathbf{2 0 0 3}$ & $\mathbf{2 0 0 4}$ & $\mathbf{2 0 0 5}$ & $\mathbf{2 0 0 6}$ & $\mathbf{2 0 0 7}$ & $\mathbf{2 0 0 8}$ & $\mathbf{2 0 0 9}$ & $\mathbf{2 0 1 0}$ & $\mathbf{2 0 1 1}$ & $\mathbf{2 0 1 2}$ & \\
\hline Estonia & 3706 & 6523 & 7072 & 4753 & 4228 & 2124 & 1670 & 1184 & 1513 & 1156 & \\
\hline Latvia & 10049 & 16064 & 19169 & 16439 & 6826 & 3004 & 2080 & 2336 & 2467 & 2213 & \\
\hline
\end{tabular}

Sources: For Estonia, 'Citizenship'; for Latvia, PMLP, 'Statistics on naturalization', 28 February 2013, available on the PMLP website at www.pmlp.gov.Iv/en/statistics/citizen.html (viewed 8 May 2013)

Despite the fact that some form of citizenship became accessible to almost all post-war settlers in Estonia and Latvia, many have not taken any steps to naturalize. Survey data of non-citizens in Estonia and Latvia suggest that the lack of motivation to naturalize is the result of a combination of psychological barriers, such as finding the process 'humiliating' or considering that citizenship for them should be 'automatic', and linguistic concerns, including being unable to pass the language examinations. ${ }^{7}$ Thus, at the start of 2013, Latvia still had 297,883 'non-citizens' and Estonia had 90,533 'aliens'. ${ }^{8}$ While the latter have the right to vote in municipal elections, non-citizens in Latvia do not. However, both sets of non-citizens have internationally recognized travel documents and benefit from facilitated travel to Russia and the CIS countries. They also enjoy most of the same social and economic rights as citizens, though Latvia in particular has barred non-citizens from

7 See PMLP, 'Pētijums: Nepilsonu viedoklis par Latvijas pilsonibas iegusanu', 2011, 11, available on the PMLP website at www.pmlp.gov.lv/lv/par_pmlp/publikacijas/ petijumi.html (viewed 9 April 2013); Kvantitatīos un kvalitatīos pètījums par sabiedrības integrācijas un pilsonības aktuālajiem aspektiem, 2008, 21, available on the Ministry of Education and Science, Republic of Latvia website at http://izm.izm.gov.lv/upload_file/ jaunatne/petijumi/Cela_uz_pilsonisku_sabiedribu_06112008[1][1].pdf (viewed 1 May 2013); Poleshchuk, Non-Citizens in Estonia, 19. All translations are by the authors unless otherwise stated.

8 For Latvia, see PMLP, 'Latvijas iedzīvotāju sadalījums pēc valstiskās piederības'; for Estonia, see 'Citizenship'. 
working in most civil service jobs in accordance with the Latvian State Civil Service Law. ${ }^{9}$

\section{The post-Soviet transformation and the 'nationalization' of the linguistic sphere}

The political domination of the 'titular nations' was used to bring about the 'nationalization' of the linguistic sphere. Throughout the 1990s, the core policy direction in all three Baltic states involved strengthening the 'titular' languages vis-à-vis Russian. This was initially done primarily through the use of 'sticks', namely, attempts to regulate language use through legislation. The use of 'carrots' - making the titular languages attractive and accessible, and providing assistance in acquiring them-followed later, primarily as the result of international support and pressure.

In 1992 Latvian legislators amended the language act substantially, making knowledge of Latvian a prerequisite for many posts in the public and private sectors. Tens of thousands of people were required to undergo language testing and, thenceforth, state-funded higher education was available only in Latvian. ${ }^{10}$ A similar process took place in Estonia, where legislators adopted a new language law in 1995 requiring knowledge of Estonian for many posts and instituting a similar process of mass proficiency testing. ${ }^{11}$ Lithuania began to implement language testing in 1993, but the significantly smaller Russian population, as illustrated in Table 1, and the higher level of 'titular' language knowledge among the Russian population, as illustrated in Table 2, meant that language issues generated much less controversy in Lithuania than in Estonia or Latvia. ${ }^{12}$

The United Nations Development Programme (UNDP) and the EU played a critical role in assisting Latvia and Estonia in developing and funding language training programmes. In 1994 and 1995, UNDP helped the Latvian government devise, then implement, the ten-year National Programme for Latvian Language Training, which developed new methodologies for

9 See James Hughes, "Exit" in deeply divided societies: regimes of discrimination in Estonia and Latvia and the potential for Russophone migration', Journal of Common Market Studies, vol. 43, no. 4, 2005, 739-62; the 2001 Latvian State Civil Service Law is available online at www.likumi.lv/doc.php?id=10944 (viewed 19 April 2013).

10 See Angelita Kamenska, The State Language in Latvia: Achievements, Problems and Prospects (Riga: Latvian Centre for Human Rights and Ethnic Studies 1995).

11 'Minority protection in Estonia', in EU Accession Monitoring Program, Monitoring the EU Accession Process: Minority Protection (Budapest: Open Society Institute 2001), 188244 (190-2).

12 Priit Järve, 'Language battles in the Baltic states: 1989-2002', in Farimah Daftary and Francois Grin (eds), Nation-Building, Ethnicity and Language Politics in Transition Countries (Budapest: Local Government and Public Service Reform Initiative, Open Society Institute 2003), 73-105 (91). 
teaching Latvian as a second language, prepared teacher trainers and drafted teacher training materials. The programme then provided free language training to various target groups. ${ }^{13}$ It was taken over by the government and turned into a standing agency in 2004. In Estonia, a similar initiative was launched, but only in 1998, under the auspices of the EU's PHARE programme. $^{14}$

In 1998, both Estonia and Latvia passed new language legislation that provoked strong criticism from the European Commission. The early versions, debated from 1997 to the end of 1999, called for significant state interference in the private sector to regulate language use. In criticizing the legislation, the European Commission invoked the provisions of the Europe Agreement, claiming that such interference could hinder the free movement of people, goods and services and the establishment of companies. ${ }^{15}$ The final versions of the laws, passed in Estonia in February 1999 and in Latvia in December 1999, were deemed largely acceptable by the EU, though subsequent years witnessed continued wrangling over the implementation of the regulations. As can be seen in Table 3, minority proficiency in the national languages had increased substantially by 2005, though more than a quarter of Russian-speakers in both Estonia and Latvia claimed only 'basic' knowledge of the national languages fifteen years after independence.

Estonia drafted plans to shift to the national language as the primary medium of instruction in Russian-language secondary schools in 1993, while Latvia did so in 1998. However, due to strong domestic opposition and international pressure, both countries moderated their goals, and settled on a model in which

Table 3 Self-estimated knowledge of the national language by minorities in the Baltic states, $2005(\%)$

\begin{tabular}{lccccc}
\hline & $\begin{array}{c}\text { Able to } \\
\text { communicate }\end{array}$ & $\begin{array}{c}\text { Use almost } \\
\text { every day }\end{array}$ & $\begin{array}{c}\text { Very } \\
\text { good }\end{array}$ & Good & Basic \\
\hline Estonian Russian-speakers & 73 & 64 & 23 & 50 & 26 \\
Latvian Russian-speakers & 81 & 67 & 23 & 48 & 28 \\
Lithuanian Russian-speakers & 90 & 81 & 49 & 41 & 10 \\
Lithuanian Poles & 90 & 80 & 36 & 58 & 7 \\
\hline
\end{tabular}

Source: Eurobarometer 2005, cited in Marju Lauristin (ed.), Estonian Human Development Report 2010/2011: Baltic Way(s) of Human Development: Twenty Years On, trans. from the Estonian by Eero Pajula, Urve Kivilo, Meelis Rohtla and Wiedemanni Tõlkebüroo (Tallinn: Estonian Cooperation Assembly 2011), 119.

13 Aivars Tabuns, Nils Muiznieks, Boriss Cilevičs, Angelita Kamenska, Tatjana Liguta and Ilmars Mezs, 'National integration and social cohesion', in Nils Muiznieks (ed.), Latvia Human Development Report 1997 (Riga: UNDP 1997), 48-66 (58-60).

14 See 'Minority protection in Estonia', 209.

15 See Pettai and Kallas, 'Estonia', 111-12; Muiznieks and Brands Kehris, 'The European Union, democratization and minorities in Latvia', 44-8. 
60 per cent of the curriculum was taught in the national language or bilingually and 40 per cent in the minority language. In Latvia, the reform was implemented from 2004-7, and sparked massive protests in 2003 and 2004. This experience prompted Estonia to implement a more gradual transition, according to which Estonian would be the language of instruction in all upper secondary schools by the 2011-12 academic year. ${ }^{16}$ In Lithuania similar legislative provisions were enacted in the education law in 2011, prompting vigorous protests from the Poles and boycotts in some Polish-language schools. ${ }^{17}$

In all three countries, national authorities have argued that the goal of language and education reform has been to promote the competitiveness of minority youth by acquainting them with the national language from an early age, thus facilitating the opportunity for higher education that is available in the 'titular' languages and preparing them for the labour market. ${ }^{18}$ Indeed, knowledge of the national languages has been shown to be a critical asset in competing in the post-independence labour markets, which have undergone a massive transformation with regard to the institutionalization of the 'titular' language. ${ }^{19}$

\section{Post-Soviet socio-economic transformation and social cohesion}

Raivo Vetik and Jelena Hellemae have argued that a 'nation-state model with an ethnic connotation' and neoliberal economic policies are interrelated and mutually reinforcing, in that they both engender the creation of strongly stratified status groups, weaken the cohesiveness of society and presume group-targeted integration policies. ${ }^{20}$ All three Baltic states implemented

16 'Studies in Estonian in Russian-medium schools', available on the Estonian Ministry of Education and Research website at www.hm.ee/index.php?1510030 (viewed 8 May 2013).

17 Rokas Tracevskis, 'Third round of the Lithuanian-Polish discussions on education', Baltic Times, 19 October 2011.

18 See Nils Muiznieks, 'Minority education in Latvia: from segregation to integration', 24 July 2004, available on the Ministry of Foreign Affairs of the Republic of Latvia website at www.mfa.gov.lv/en/policy/4641/4642/FromSegregationToIntegration (viewed 30 April 2013); Gabrielle Hogan-Brun, 'At the interface of language ideology and practice: the public discourse surrounding the 2004 education reform in Latvia', Language Policy, vol. 5, no. 3, 2006, 315-35.

19 See Artis Pabriks, Etniskās proporcijas, nodarbinātība un diskriminācija Latvijā (Riga: Nordik 2002), 18-22, available online at http:/ /s3.amazonaws.com/politika/public/ article_files/1106/original/SFL_Pabriks_lv.pdf?1326907814 (viewed 30 April 2013); Kristian-Olari Leping and Ott Toomet, 'Emerging ethnic wage gap: Estonia during political and economic transition', Journal of Comparative Economics, vol. 36, no. 4, 2008, 599-619.

20 Raivo Vetik and Jelena Helemäe, 'Conclusions', in Raivo Vetik and Jelena Helemäe (eds), The Russian Second Generation in Tallinn and Kohtla-Järve: The TIES Study in Estonia (Amsterdam: Amsterdam University Press 2011), 229-38 (231). 
neoliberal economic reforms in the early and mid-1990s. In Estonia and Latvia in particular, these policies destroyed old patterns of ethnic stratification in the labour market. ${ }^{21}$ This was only possible because the political clout of Russian-speakers had been diminished through the removal of their citizenship. Data from the Norbalt living conditions survey suggest that in the 1990s Russian-speakers experienced disproportionate levels of unemployment and a greater risk of being excluded from the labour market, but no significantly greater risk of poverty due to the welfare system. ${ }^{22}$

In the 2000s, socio-economic inequality between persons belonging to different ethnolinguistic groups increased in Estonia, but decreased in Latvia. A recent study found a consistently much higher unemployment rate and greater job insecurity among minorities in Estonia and 'a tendency [for Russian-speakers] to belong to the ranks of blue collar, rather than white collar workers' ${ }^{23}$ These differences have persisted in Estonia among the younger generation of Russian-speakers, who are far less likely than their peers to get managerial, professional or specialist jobs. ${ }^{24}$ In Latvia, by contrast, the labour market proved quite successful in integrating Russian-speakers, and ethnic disparities in employment and unemployment rates had largely disappeared until the onset of the economic crisis in $2008 .^{25}$

Estonia, Latvia and Lithuania are among the nine poorest member states in the EU (referred to as 'L9' by Eurostat), where income per capita in 2009 was on average 45 per cent lower than the EU norm. While making some progress towards income convergence in the mid-2000s, the global economic crisis, which began in 2008, affected the Baltic states more severely than other EU member states. The gap between household income in the L9 states and the EU average has remained more or less the same. In Lithuania, however, it increased by one percentage point, in Estonia by two percentage points, and in Latvia by six percentage points (see Figure 2).

21 See John Dobson and Graham Jones, 'Ethnic discrimination: public policy and the Latvian labour market', International Journal of Manpower, vol. 19, no. 1/2, 1998, 31-47; Andrew Savchenko, 'Toward capitalism or away from Russia? Early stage of postSoviet economic reforms in Belarus and the Baltics', American Journal of Economics and Sociology, vol. 61, no. 1, 2002, 233-57; Mihails Hazans, 'Ethnic minorities in the Latvian labour market, 1997-2009: outcomes, integration drivers and barriers', in Nils Muiznieks (ed.), How Integrated Is Latvian Society? An Audit of Achievements, Failures and Challenges (Riga: University of Latvia Press 2010), 125-58.

22 Aadne Aasland and Tone Fløtten, 'Ethnicity and social exclusion in Estonia and Latvia', Europe-Asia Studies, vol. 53, no. 7, 2001, 1023-49.

23 Mati Heidmets (ed.), Estonian Human Development Report 2007 (Tallinn: Estonian Cooperation Assembly 2008), 53.

24 Kristina Lindemann, 'Explaining different returns from human capital in the labour market', in Vetik and Helemäe (eds), The Russian Second Generation in Tallinn and Kohtla-Järve, 93-118.

25 Hazans, 'Ethnic minorities in the Latvian labour market'. 
Figure 2 Income per capita in the Baltic states compared to the EU average (EU27 $=100$ )

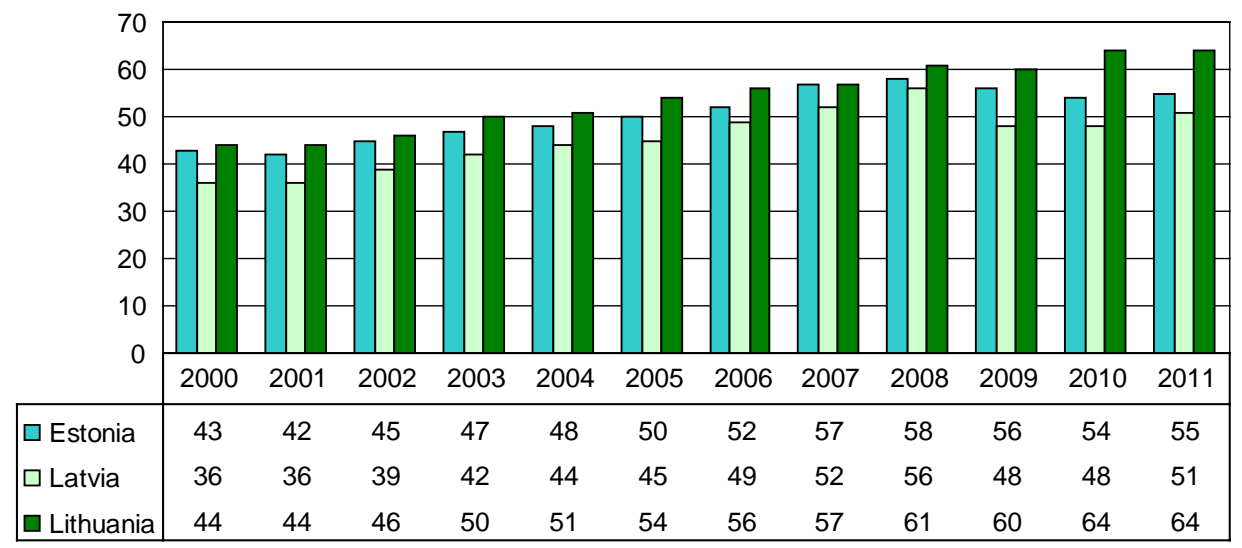

Source: Peeter Leetmaa, Denis Leythienne, Fabienne Montaigne and Pascal Wolff, 'The 9 poorest countries catching up on income per capita', Statistics in Focus (Eurostat), no. 16, 2011, Table 2, available on the Eurostat website at http://epp.eurostat.ec.europa.eu/cache/ITY_OFFPUB/KS-SF-11016/EN/KS-SF-11-016-EN.PDF (viewed 1 May 2013)

Income disparity is another source of social inequality in the Baltic states that affects not only ethnic minorities but also the rest of the population. When looking at the Eurostat data in Figure 3, it becomes evident that the income gap in the Baltic states is of continuing concern. For the whole of the EU, the wealthiest 20 per cent of households on average have an income that is 4.9 times higher than that of the poorest 20 per cent of EU households. If in 2000 Estonia had the greatest income inequality at 6.1 times the average, then by 2008 it had managed to nearly converge with the EU average. Lithuania, which had been in the best situation in the Baltic in 2000, witnessed a serious downturn in 2004, but a more positive trend thereafter. In contrast, Latvia has exhibited a steady trend of greater social stratification based on income disparity over the recent years, and in 2008 the wealthiest households had an income that was 7.3 times higher than the poorest households.

What accounts for these differences among the Baltic states? Since independence they have each taken a different development path in regard to social welfare system reforms. Even though all three Baltic states underwent liberalization, which placed greater responsibility on the individual, and (as illustrated in Figure 4) still lag way behind the EU average on the share of GDP devoted to social security, Estonia and Lithuania have steadily increased the share of GDP spent on social welfare. Latvia, on the other hand, from 2000 to 2007, continuously decreased expenditure on social security, with a slight increase only in 2008. Moreover, throughout this period, social expenditure per capita in Latvia was significantly smaller than in Estonia or Lithuania. Thus, for example, in 2000, per capita annual social security expenditure in Latvia (€547) was only 87 per cent of the level in Estonia and 97 per cent of the level in Lithuania. By 2008 the difference had 
Figure 3 Average income inequality in the Baltic states (by quintile share ratio S80/S20)

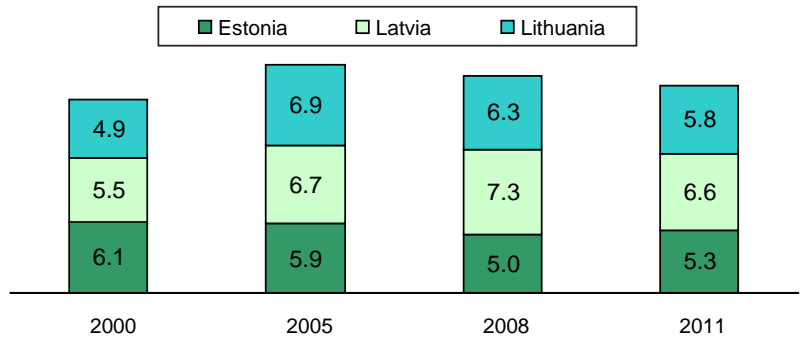

Source: For 2000, Leetmaa, Leythienne, Montaigne and Wolff, 'The 9 poorest countries catching up on income per capita', Table 4; for 2005-11, Eurostat, 'S80/S20 income quintile share ratio by sex and selected age group', 27 May 2013, available on the Eurostat website at http://appsso.eurostat.ec. europa.eu/nui/show.do?dataset=ilc_di11\&lang=en (viewed 3 June 2013)

increased dramatically and Latvia's expenditure $(€ 1,283$ per capita per annum) was equal to only 71 per cent of that in Estonia and 81 per cent of that in Lithuania (see Figure 4).

Thus, even though we have argued that socio-economic inequality between persons belonging to different ethnolinguistic groups grew deeper in Estonia in the 2000s, thanks to its commitment to social welfare the income disparity has lessened, Estonia is not the least egalitarian of the three Baltic states. In other words, although Russian-speakers in Estonia may be more likely to be unemployed or belong to the ranks of blue-collar workers ${ }^{26}$ social security benefits will ensure that, in terms of social goods, they will be on more equal footing with their Estonian counterparts. However, in Latvia, where the labour market has been assumed to have

Figure 4 Social security expenditure in the Baltic states, 2000-9 (\% of GDP)

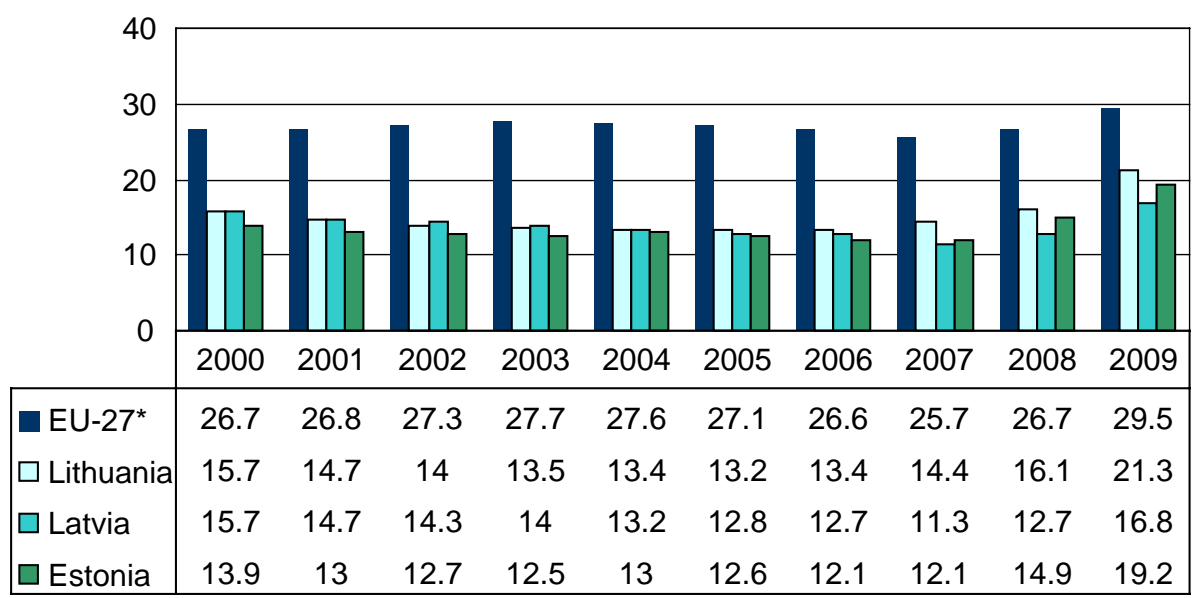

* The figures for 2000-4, before the EU expanded to include 27 countries, are for the Euro area.

Source: Eurostat, 'Social protection statistics', September 2012, available on the Eurostat website at http://epp.eurostat.ec.europa.eu/statistics_explained/index.php/Social_protection_statistics (viewed 1 May 2013) 
integrative functions, the ever decreasing commitment to social security has resulted in more socio-economic inequality and stratification, posing longterm challenges to social cohesion, not only among ethnolinguistic groups but the population as a whole.

\section{European pressure and the development of integration policy}

As the Baltic states approached EU membership, Estonia and Latvia came under significant pressure to develop policy frameworks to integrate Russian-speakers. The Estonian parliament adopted the policy document 'The Integration of Non-Estonians into Estonian Society: The Principles of National Integration Policy' on 10 February 1998; and, on 14 March 2000, it approved the state programme 'Integration in Estonian Society 2000-2007', which set out three goals: 'linguistic-communicative integration', 'legal-political integration' and 'socio-economic integration'.

However, the various sub-programmes within the larger framework clearly put the emphasis on the acquisition by minorities of the Estonian language through the improvement of Estonian language competence in minority elementary and secondary schools, including a shift in vocational training to the Estonian language, and the organization of Estonian language-training for minority teachers, journalists and other adults. ${ }^{27}$ While reference was made to the preservation of cultural diversity, the focus was clearly on the linguistic deficit of minorities.

Estonia adopted the follow-up 'Estonian Integration Strategy 2008-2013', which sets out, as an objective, 'to support the shared feeling of belonging in the Estonian society among all permanent residents through sharing common values and knowledge of the national language' ${ }^{28}$ While continuing to stress acquisition of Estonian, this strategy also includes addressing labour market and income inequalities, regional differences, the integration of new immigrants and differences in civil society participation rates of Estonians and Russian-speakers.

The Latvian government took longer to approve a similar framework and the end product was more diffuse. While a government steering group began work on a framework document in March 1998, the 'National

26 Heidmets (ed.), Estonian Human Development Report 2007, 53.

27 'State programme: “Integration in Estonian Society 2000-2007"', approved by the Government of Estonia, 14 March 2000, available on the Estonian Ministry of Culture website at www.kul.ee/webeditor/files/integratsioon/state_programme111. pdf (viewed 2 May 2013).

28 'Estonian Integration Strategy 2008-2013 (Unofficial translation)', 3, available on the Estonian Ministry of Culture website at www.kul.ee/webeditor/files/integratsioon/ Loimumiskava_2008_2013_ENG.pdf (viewed 2 May 2013). 
Programme on the Integration of Society in Latvia' was not adopted by the government until February 2001. Because of political disagreements, the programme was a messy compromise in which politically sensitive minority-related issues (citizenship, language) were merged into a single document along with issues pertaining to regional development and social inclusion. As Juris Rozenvalds has noted elsewhere, despite reference to the two-way nature of integration, 'the emphasis is on the tasks for minoritiesthe need to accept Latvian culture, understand history, be loyal, believe they are needed, etc. ${ }^{29}$

In 2011 the Latvian government adopted the new policy document 'Basic Principles on National identity, Civil Society and Integration Policy $(2012-2018)^{\prime} .{ }^{30}$ This document has a more ethnocentric focus than its predecessor, stressing the special role of Latvians as the 'nation of state', and the responsibility of the 'Latvian language and cultural space' as the 'basis of national identity' and a 'cohesive social memory'. A sociological survey conducted in 2010 asked respondents whether they supported the statement that the unity of Latvian society should be based on the Latvian language and culture'. While 89 per cent of ethnic Latvian respondents supported this statement, only 46 per cent of Russians did so, ${ }^{31}$ suggesting serious problems ahead in putting the strategy into practice.

To implement the programmes, both Estonia and Latvia created two different kinds of institutional set-ups. First, both countries established integration bodies: autonomous government agencies tasked with organizing grants competitions and integration funding initiatives 'from below'. While no detailed analysis of the Estonian foundation's work has been conducted, an analysis of the Latvian foundation's work for 2001-6 found that only 20 per cent of the projects supported in the early years involved face-to-face intercultural contact. ${ }^{32}$

A second form of implementing agency was a separate ministry. From 1997 through 2009, Estonia had a Minister for Population and Ethnic Affairs, while Latvia had a Special Assignments Minister for Social Integration Affairs from 2002-9. The effectiveness of these offices was hampered by

29 Juris Rozenvalds, 'The Soviet heritage and integration policy development since the restoration of independence', in Muiznieks (ed.), How Integrated Is Latvian Society?, 33-59 (55).

30 'Nacionālās identitātes, pilsoniskās sabiedrības un integrācijas politikas pamatnostādnes (2012-2018)', 20 October 2011, available on the Ministry of Culture of the Republic of Latvia website at www.km.gov.lv/lv/doc/nozaru/integracija/Pamatnostadnes/KMPam_071011_integ.pdf (viewed 6 May 2013).

31 Brigita Zepa and Evija Kļave, Latvija: pārskats par tautas attīstību. 2010/2011: Nacionālā identitāte, mobilitāte un rīcībspēja (Riga: Latvijas Universitātes Sociālo un politisko pētījumu institūts 2011), 25.

32 Ilona Kunda, 'The Society Integration Foundation and "ethnic integration"', in Muiznieks (ed.), How Integrated Is Latvian Society?, 61-89 (83). 
frequent changes of minister and, concomitantly, frequent changes in policy emphasis. In 2009, in the context of budget austerity, separate ministries devoted to promoting integration were scrapped in both countries and their functions were distributed to various other ministries. While considerable resources have been expended on seeking to promote integration, the outcome in terms of strengthening the sense of belonging to the Baltic states, especially among Russian-speakers, has been quite limited.

\section{Impact of integration policies on sense of belonging}

Thus far, this article has addressed the processes of transition in the postSoviet Baltic states, and the challenges to social cohesion posed by ethnicity and the particular historical context, focusing on the role of citizenship, socio-economic conditions and language policy. The following section looks at the relationship between social cohesion and the sense of belonging, employing the understanding that 'social cohesion is a set of social processes that help instill in individuals the sense of belonging to the same community and the feeling that they are recognised as members of that community ${ }^{\prime 33}$ Specifically, this section looks at the relative success or failure of integration policy in achieving a sense of belonging among the Russian-speaking population in each Baltic state, drawing on theoretical discussions of the concept of belonging and empirical research. The survey data illustrate how the particular historical context, and the approach to integration used, hinder the development of a sense of belonging among the Russian-speakers in Latvia and Estonia.

John Shotter's discussion of the concept of 'belonging' combines rational considerations, such as the ability to influence decision-making and shape the reality of everyday life, with the feeling that one's voice is recognized and heard. ${ }^{34}$ Such circumstances have to be grounded in a community that provides meaning and that is envisioned as a common endeavour, thus encouraging a sense of home. In social psychology, the factors of territorial and relational dimensions are held to be instrumental in the development of a sense of community. The territorial dimension, or physical rootedness, refers to the territory inhabited and the belonging conditioned by landscape. The relational dimension, or the social bonding aspect, refers to the

33 Jane Jenson, Mapping Social Cohesion: The State of Canadian Research, Canadian Policy Research Networks (CPRN) Study no. F/03 (Ottawa: Renouf Publishing 1998), 4, available on the CPRN website at www.cprn.org/documents/15723_en.pdf (viewed 2 May 2013).

34 John Shotter, 'Psychology and citizenship: identity and belonging', in Bryan S. Turner (ed.), Citizenship and Social Theory (London and Newbury Park, CA: Sage Publications 1993), 115-38 (125-6). 
quality and nature of the relationships between the inhabitants within the territory. ${ }^{35}$

Each Baltic state will be viewed as the territorial object of attachment. The only distinction that will be made will be between individuals 'for whom one locality is all-inclusive of their remembered experiences, and those for whom many places mark their histories and whose sense of belonging is to that extent multilocal'. ${ }^{36}$ This distinction is particularly applicable because the survey data cited below show that a large percentage of Baltic Russianlanguage speakers identify with Russia as their homeland, irrespective of their country of residence.

The discussion of sense of belonging in the Baltic states is hampered by the fact that little comparative data on all three countries exists. The last comparable data on the territorial identification of natives and Russian-speakers in all three Baltic states date from $2004 .{ }^{37}$ Using these data, Kjetil Duvold has written about the territorial identification of Russianspeakers in the Baltic states, ${ }^{38}$ claiming that Baltic minorities did not identify themselves with their respective countries of residence, as opposed to the natives whose primary identification was with the national territory. A significant portion of Russians in Latvia, 40 per cent, and Russians in Estonia, 43 per cent, identified themselves with Russia. Only a small portion, 2 per cent of Russian-speakers in Estonia and 5 per cent of Russian-speakers in Latvia, stated that their primary identification was with their country of residence. $^{39}$

The situation in Lithuania was surprisingly different. There, the majority of Russian-speakers chose 'Lithuania' as either their primary or secondary identity, although 10 per cent still identified with Russia. ${ }^{40}$ Identification with Russia undermines a sense of belonging, as Gerli Nimmerfeldt has shown using Estonian data. In her analysis, identification with Russia, or considering Russia as the homeland, has a significant impact on feelings of belonging to Estonia: 'The odds of feeling strongly connected to Estonia are

35 Stephanie Riger and Paul J. Lavrakas, 'Community ties, patterns of attachment and social interaction in urban neighborhoods', American Journal of Community Psychology, vol. 9, no. 1, 1981, 55-66.

36 David Parkin, 'Foreword', in Nadia Lovell (ed.), Locality and Belonging (London and New York: Routledge 1998), x-xiv (xiii).

37 Richard Rose, New Baltic Barometer VI: A Post-Enlargement Survey, Studies in Public Policy, no. 401 (Glasgow: University of Strathclyde, Centre for the Study of Public Policy 2005).

38 Kjetil Duvold, 'If push comes to shove: territorial identification among the Baltic Russians', in Uncertain Transformations-New Domestic and International Challenges: Proceedings of the International Conference, Riga, November 9-11, 2006 (Riga: LU Akadēmiskais apgāds 2007), 293-304.

39 Ibid., 298.

40 Ibid., 298-9. 
3.33 times higher for those respondents who do not consider Russia their homeland compared to those who do. ${ }^{41}$

To account for inter-ethnic and Baltic variations, Duvold blames Soviet history, and the legal steps taken in re-establishing independence, or legal restorationism. ${ }^{42}$ Furthermore, Rogers Brubaker has discussed at length the Soviet practice of 'nativization' (korenizatsiia), and how territorial and personal nationhoods were institutionalized by employing an ethnic/ primordial conception of nation. ${ }^{43}$ In the Soviet Union, the titulars were assigned 'ownership' of their respective territories, or republics, making them the legitimate inhabitants. The Soviet practice of ascribing identities to people based on their ethnic origin and language spoken, and the belief that some people were the rightful 'owners' or residents of the respective territories, carried over into the independent Baltic states in their conception of the nation state. Accordingly, people's sense of belonging is influenced by the primordial construction of nation and they 'tend to identify themselves in ethno-lingual terms', ${ }^{44}$ especially in Estonia and Latvia.

The 2004 survey data can be further supplemented with more resent research findings in the individual states that support the earlier conclusions. For example, in a 2006 survey conducted in Latvia that asked 'How close is your personal bond with Russia?', 34 per cent of Russian-speakers said their bond was 'close' and a further 10 per cent said their bond was 'very close'. ${ }^{45}$ When looking at the latest survey data from Lithuania, the earlier conclusion that Lithuanian Russian-speakers tend to identify with Lithuania is also corroborated. The 2009-10 European, National and Regional Identities (ENRI) project found that in Lithuania 80.6 per cent of Russian-speakers expressed a closeness to Lithuania. ${ }^{46}$

This closeness can be explained by the way in which Lithuania went about re-establishing independence and granting citizenship to Soviet-era migrants. Lithuania chose the 'zero option' and granted citizenship to all persons who were legal permanent residents of the country. Thus Russian

41 Gerli Nimmerfeldt, 'Sense of belonging to Estonia', in Vetik and Helemäe (eds), The Russian Second Generation in Tallinn and Kohtla-Järve, 203-28 (217).

42 Duvold, 'If push comes to shove', 298.

43 Roger Brubaker, Nationalism Reframed: Nationhood and the National Question in the New Europe (Cambridge: Cambridge University Press 1996).

44 Duvold, 'If push comes to shove', 298.

45 Brigita Zepa (ed.), Integrāaijas Prakse un Perspektī̃as (Riga: Baltic Institute of Social Sciences 2006), 73.

46 Arvydas Matulionis, Vida Beresnevičiūtè, Tadas Leončikas, Monika Frejjutè-Rakauskienè, Kristina Šliavaitė, Hans-Georg Heinrich and Olga Alekseeva, The Russian Minority in Lithuania, ENRI-East Research Report no. 9, 2011, 28, available on the ENRI-East website at www.enri-east.net/wp-content/uploads/The_Russian_Minority_ in_Lithuania.pdf (viewed 2 May 2013). 
and Polish nationals 'were granted access to Lithuanian citizenship right from the start'. ${ }^{47}$ This is important because formal membership in a community has long been believed to be an effective tool for overcoming societal divisions based on culture, providing a sense of belonging and as a means of promoting social cohesion. ${ }^{48}$

The Latvian and Estonian political elite chose the nation-state model based on the legal continuity principle as a means of overcoming the changes to ethnic composition during the Soviet period, and as the basis of national identity. Citizenship was automatically granted only to pre-war residents and their descendants, excluding all Soviet-era migrants. Those Russianspeakers who had arrived in Estonia or Latvia during the Soviet period and who wished to acquire citizenship had to demonstrate linguistic competence and pass a civics examination. This has resulted in a large 'stateless' population in both Estonia and Latvia. Naturalization of this 'stateless' Russian-speaking population is often mentioned as the ultimate goal of integration, and seen as the way to overcome social cohesion problems and promote identification with the country of residence. ${ }^{49}$

An immigrant's willingness to undergo the naturalization process has traditionally been viewed as an indicator of their sense of belonging to the host society. ${ }^{50}$ However, data on whether citizenship status alone directly impacts the sense of belonging of Russian-speakers in the Baltic countries are inconclusive. The 2004 New Baltic Barometer data show that there is no direct correlation between the citizenship status of Russian-speakers and their identification with the country of residence. ${ }^{51}$ Therefore, integration initiatives that simply focus on increasing naturalization rates in order to improve social cohesion are almost certainly inadequate.

It is true that a pre-existing sense of belonging can serve as motivation for completing the naturalization process and for wanting to formalize a sense of attachment. However, simply awarding formal membership in a community is not enough to encourage the development of a sense of belonging. The fact that the sense of belonging to Lithuania is more pronounced among Russian-speakers and Russian-speaking Lithuanian citizens seems to

47 Duvold, 'If push comes to shove', 297.

48 Peter Kivisto, 'Inclusion: Parsons and beyond', Acta Sociologica, vol. 47, no. 3, 2004, 291.

49 David Laitin, Identity in Formation: The Russian-Speaking Populations in the Near Abroad (Ithaca, NY and London: Cornell University Press 1998); Pål Kolstø (ed.), NationBuilding and Ethnic Integration in Post-Soviet Societies: An Investigation of Latvia and Kazakstan (Boulder, CO: Westview Press 1999); David J. Galbreath, Nation-Building and Minority Politics in Post-Socialist States: Interests, Influences and Identities in Estonia and Latvia (Stuttgart: Ibidem 2005); Muiznieks (ed.), How Integrated Is Latvian Society?.

50 Henry P. H. Chow, 'Sense of belonging and life satisfaction among Hong Kong adolescent immigrants in Canada', Journal of Ethnic and Migration Studies, vol. 33, no. 3, 2007, 511-20 (513).

51 Duvold, 'If push comes to shove', 301. 
suggest that the process of awarding citizenship, specifically early inclusion in the national political community, may have had an influence on the overall sense of attachment.

Also important are the actual rights and privileges citizenship bestows, and the sacrifices, in terms of ethnic identity, that are required in return. As the central argument of the book Citizenship in Diverse Societies makes clear, the sense of belonging to a common overarching citizenship identity can only be achieved if members are afforded full and active participation in the larger society, while also retaining a minority identity if desired.$^{52}$ This argument highlights the second major shortcoming of integration policy in Estonia and Latvia: the emphasis on cultural and linguistic assimilation.

In the integration policy documents of Estonia and Latvia there is a tendency to impose a preconceived set of values, with an emphasis on the majority identity, and very little mention of the protection afforded to minority identities. This has been highlighted by Estonian studies indicating 'that Russians perceive the Estonian integration policy as forced "assimilation'". ${ }^{53}$ In the Latvian case, Juris Rozenvalds has noted elsewhere the onesided approach to integration by Latvian authorities, placing the emphasis on the need for minorities to learn the Latvian language and understand the country's history and culture. ${ }^{54}$

The assimilationist tendencies of these integration policies affect both the sense of belonging and the perception of cultural threat. Thus, the Estonian TIES study shows that for Russian-speakers the greatest impact on the chances of feeling a strong sense of belonging to Estonia relates to a lack of perception of threat on the cultural identity'. ${ }^{55}$ In that study, those Russians who did not perceive a threat to their cultural identity were 8.83 times more likely to feel a strong connection to Estonia. ${ }^{56}$ In the Latvian case, the perception of a threat to language and culture has been noted on both sides. In a 2006 study, 34 per cent of Russian-speaking respondents claimed that Russian language and culture in Latvia is under 'somewhat of a threat', and a further 11 per cent expressed feeling a 'serious threat'. ${ }^{57}$ Of the Latvian respondents, 35 per cent claimed that Latvian language and culture in Latvia is under 'somewhat of a threat', and a further 9 per cent claimed feeling a 'serious threat'. ${ }^{58}$ This perceived threat to the Latvian language and culture has both reinforced the emphasis placed in integration policy on knowledge of the Latvian language and its use, and the perception among the minority Russian-speakers that their culture is under threat.

52 Will Kymlicka and Wayne Norman (eds), Citizenship in Diverse Societies (Oxford and New York: Oxford University Press 2000).

53 Nimmerfeldt, 'Sense of belonging to Estonia', 217.

54 Rozenvalds, 'The Soviet heritage and integration policy development', 55.

55 Nimmerfeldt, 'Sense of belonging to Estonia', 221.

56 Ibid., 216.

57 Zepa (ed.), Integrācijas Prakse un Perspektīoas, 76.

58 Ibid., 75. 


\section{Challenges facing social cohesion in the Baltic states}

In addressing the theme of social cohesion, the aim of this article has been to demonstrate the struggles faced by Lithuania, Latvia and Estonia in overcoming the ethno-linguistic cleavages that are the legacy of Soviet rule, and to look at the particular approaches taken by the Baltic states in facilitating social inclusion and integration. The analysis suggests that, in their integration policies, the Baltic states have stressed the imposition of the majority language and culture on minorities, while neglecting systematic efforts to address socioeconomic inequality in general and ethnic inequality in particular. All three states have struggled to overcome the Soviet policies of bilingualism and restore the primacy of the titular language. However, the perception of threat to the Lithuanian language and culture has been less salient due to the smaller overall total percentage of Russian-speakers in the country. Thus Lithuania has been able to opt for early inclusion of Russian-speakers in the polity and, as a result, generate a greater sense of belonging to Lithuania among them.

In Estonia and Latvia, the internalization of cultural norms and language knowledge has been regarded as a prerequisite for access to citizenship and formal membership. Yet this approach has largely failed in fostering a sense of belonging. The analysis suggests that there is a serious misfit between the stated policy goal of integration and the attempts to promote social cohesion in the Baltic states. The perceived threat to minority cultural identity resulting from assimilationist policies has been shown to lower significantly the odds that feelings of belonging will develop towards the country of residence. The article suggests that there are critical challenges ahead for Estonia and Latvia in achieving social cohesion, in the sense of membership within the same community and feelings of mutual recognition.

Nils Muiznieks is the current Council of Europe Commissioner for Human Rights. Prior to this appointment, he was director of the Advanced Social and Political Research Institute at the Faculty of Social Sciences of the University of Latvia in Riga (2005-12). He has also been Chairman of the European Commission against Racism and Intolerance (2010-12), the Latvian minister responsible for social integration, anti-discrimination, minority rights and civil society development (2002-4), and director of the Latvian Centre for Human Rights and Ethnic Studies (1994-2002). He has published extensively on human rights issues, in particular on racism, discrimination and minority rights. This article does not represent the official position of the Council of Europe Commissioner for Human Rights. Email: commissioner@coe.int

Juris Rozenvalds is Professor of Political Theory in the Department of Political Science and Dean of the Faculty of Social Sciences at the University of Latvia. His recent works include three edited volumes: How Democratic Is Latvia: Audit of Democracy (2005); How Democratic Is Latvia: Monitoring of Democracy 2005-2007 (2007); and Latvia Human Development Report 2008/2009: 
Accountability (2010). His research interests include democratic theory, the political role of intellectuals, and measuring the quality of democracy. Email: Juris.Rozenvalds@lu.lv

Ieva Birka is a doctoral candidate in the Department of Political Science at the University of Latvia. She is also a member of the Central Election Commission of Latvia, and author of the article 'Relationship between History and a Sense of Belonging: Russian Speaking Minority Integration in Latvia' (Central European University Political Science Journal, vol. 6, no. 3, 2011). Her academic interests include nationalism, migration studies, group solidarity and belonging. Email: ievagruzina@gmail.com 